\title{
How Change Adaptability Helps in Times of Pandemic and can be Enhanced in Remote Environment
}

\author{
Michael Hagemann \\ Pegaso International, Malta \\ hagemannmichael@web.de
}

Purpose: The question of how people cope with the increasing pace of change remains challenging. This study deals with how people can learn - remotely - to adapt better and faster to change.

\begin{abstract}
Study design/methodology/approach: In a literature review, the concept of change adaptability and its practical relevance will be explored. Concepts of adult learning and remote learning will be investigated, and the results will be synthesized to create a model of how Change Adaptability can be learned remotely.
\end{abstract}

Findings: A model has been created showing how Change Adaptability can be learned in its most critical detailed aspects in a remote context.

Originality/value: A new and unique model proposed how Change Adaptability can be learned remotely.

\section{Introduction}

From a changed perspective, the pandemic represents multiple changes. Habits in different places are interrupted. For example, relationships can no longer be lived as they were before. The social structure as a whole changed, leisure habits are disrupted. In the professional sphere, the collapse of entire industries, such as the aviation or tourism industries or continuous remote working, represent significant change challenges for many. Even when professional social life is completely digitalized, this is a change that should not be underestimated. However, people deal with change very differently. Depending on personality, attitude, experience, and environment, change is perceived as more straightforward or, for others, more challenging to deal with (Hagemann 2020). In any case, the ability to cope with change is becoming increasingly important. Under the heading of change adaptability, research is looking into which elements help those affected by the transition to deal with change positively. The most comprehensive framework, which is subsequently referred to by most researchers, comes from Karen van Dam (2009). Now, there is, in general, the fundamental question on how the theoretical framework translates into practice, i.e., how the individual elements of change adaptability can be taught and learned. On the other hand, whether and how Change Adaptability can be learned or enhanced as a skill in a digital environment, especially in remoteworking. In other words: How must learning be structured so that change adaptability can be increased as a capacity in a remote environment?

This study aims to bridge research, pedagogy, practice and learning in virtual environments. Research could produce the best results; however, they remain theoretical if these are not put into practice pedagogically. Even if good pedagogical concepts are built on research but are no good in practice, they are not very effective. Conversely, good pedagogical concepts that are also implemented in practice but lack the research basis are not sustainable. And the same applies to all aspects: learning must and will be more and more digital and thus also possible "remotely" (Araya 2020).

A recent study is devoted to education and adaptability. However, it presents an educational framework and does not examine how the main elements of adaptability can be learned in a remote environment (Green et al., 2021). Another study investigated and confirmed in college students that a higher level of adaptability correlates with better coping with the pandemic situation (Besser et al., 2020). 
However, this study has a different goal: The primary orientation of this study can therefore be summarized as follows: First, Change Adaptability is defined in principle and then "translated" into elements suitable for practice. Then we examine the general question on how adults actually learn. These findings are then carried forward into the investigation of how adults learn remotely. These findings can then be finally merged into a new construct that shows how the practice-suitable elements of change adaptability can be learned in remote environments.

\section{Methodology}

A literature review shows that there is a vast amount of literature on all areas covered, both on change adaptability and principles of adult learning and learning in remote environments. Therefore, from the beginning, the methodological guideline was to identify approaches that have been widely accepted and referred to by most scholars. These would serve us as the basis for this work. Of necessity, not every aspect of the respective topic can be illuminated. Still, on the other hand, this approach makes it possible to arrive at a scientific result that is relevant to practice.

Therefore, as a systematic approach to Change Adaptability, mainly basic research regarding Change Adaptability was consulted, which is connected in the respective explanations with another essential work of adult learning: experimental learning. This pedagogical construct, in turn, forms the basis for the application to remote learning, which is also sharpened to the central dimension. Finally, the primary findings of Change Adaptability in the practice of adult learning and remote learning are merged into a new construct.

\section{A basic definition of change adaptability}

Different scholars have approached the topic from different perspectives. Pulakos comes up with an 8 dimensions taxonomy of adaptive performance (Pulakos et al. 2000). For Ployhart and Bliese, partly building on Pulakos' construct, Individual Adaptability "represents an individual's ability, skill, disposition, willingness, and/or motivation, to change or fit the different task, social, and environmental features." (Ployhart and Bliese, 2006). Wanberg and Banas come up with predictors of openness to change (Wanberg \& Banas, 2000). Judge et al. describe adaptability from a managerial perspective (Judge et al., 1999).

Van Dam defines Individual Adaptability as the "employees' underlying potential as derived from cognitive, affective and behavioural resources that can be applied to effectively adjust and/or anticipate to task-related, environmental and vocational demands." (van Dam, 2013a).

This definition implies that people can deliberately make use of their resources and can develop them. This paper aims not to give a comprehensive comparison of all the different concepts on human adaptability but to bridge the gap between science and practice based on one concept. A thorough review of the various concepts had shown that Van Dam's framework is most suitable for this purpose. Hence, a basic definition of change adaptability can be summarized in the individual capacity to change, building on cognitive, affective and behavioural resources to increase the personal competency and motivation to adjust to change.

But what does Change Adaptability mean on a deeper level? As already mentioned, Karen van Dam (2013b) has extensively studied how Change Adaptability can be formed. She distinguishes between cognitive, affective and behavioural change adaptability. Even if there is no comprehensive review provided, the framework as such is noteworthy.

According to Van Dam, cognitive adaptability is based on situation awareness, mental abilities (cognitive flexibility and focused attention), and an adaptive orientation, which consists of different characteristics that help to face change positively. These traits include Optimism, 
Hope, Self-Efficacy, Control, Challenge, Open-mindedness, Learning Orientation and Curiosity.

Affective adaptability benefits from the resources resilience, positive emotions and emotion regulation. The more employees can use these resources, the easier it is for them to deal with change.

In behavioural adaptability, the mentioned resources consist of adaptive skills and behavioural tendencies such as proactivity, problem-focused coping or approach-avoidance motivation. The competence as such can be distinguished from the behaviour displayed. In change, for example, employees may not adapt for other reasons, even though they can do so (Endsley 1995). Studies on this subject contain various concepts, ranging from more specific to more general adaptability skills or behaviour concerning change.

\section{How can the theoretical construct of change adaptability be "translated" into elements suitable for practice?}

The three elements of change adaptability can be well described in terms of cognitive, affective and behavioural resources. However, the "translation" to a deeper level to elements that can be implemented and applied in practice is still missing. Therefore, the three elements will now be developed more deeply to become applicable in practice.

Cognitive adaptability: As long as a given situation and environment is stable, there is no great need for change. But even if there is a lot of change, it does not mean that the person is aware of it. Therefore, the first element that supports cognitive adaptability is to raise awareness of the need for change. The literature calls the comprehensive skill behind change awareness: situation awareness, which is defined by Endsley (1995) as "the perception of the elements in the environment within a volume of time and space, the comprehension of their meaning, and the projection of their status in the near future." Situation awareness is the prerequisite for change awareness. Suppose the environment is not as such inducing the change. In that case, awareness can be created: For example, lectures or impulses that point out exactly what is changing can work to make those affected realize that an appropriate response to the change is needed from them.

Further aspects of cognitive adaptability consist of cognitive flexibility and focused attention. For example, looking at a situation with a new, fresh eye and trying to think differently than usual constitutes cognitive flexibility. According to Kaufman (2013) and $\mathrm{Xu}$ (2018), intellectual engagement and cognitive ability are associated with creativity and can be trained over time.

Ignoring distractions and staying focused constitutes focused attention. The ability to stay focused can be developed through various interventions such as the right environment (close door, no tech devices, tidy desk, etc.), proper caffeine consumption (Nehlig 2010), planning the time, including appropriate breaks, such as with the Pomodoro technique (Cirillo 2006), and also healthy eating, getting enough sleep and using mindfulness techniques. (Harvard Health Publishing, 2017). In addition, there is exhaustive scientific research on the fact that healthy, sufficiently long and proper sleep helps with the brain's memory performance and thus also with focus (Rasch and Born 2013).

The last aspect of cognitive adaptability consists of a basic mental positive state of mind, called "adaptive orientation" (van Dam 2011), including resources like optimism, hope, self-esteem, self-efficacy, control, challenge, open-mindedness, learning orientation, curiosity etc.

Martin Seligman's extensive research shows that optimism can be learned (Seligman 2011). The other resources can be supported using cognitive behavioural therapy (CBT) and Rational 
Emotive Behaviour Therapy (REBT). (Ellis and MacLaren 2001; Beck 2019). The relevant research shows: The better all abilities are developed, the greater the change adaptability.

Affective Adaptability: First of all, there are two aspects to be mentioned here. Affective adaptability consists of remaining fundamentally positive in change situations and recovering quickly when the mood has been dampened or negative feelings have developed.

The ability to develop positive emotions and persevere, especially in change situations, helps change adaptable. Positive emotions have a particularly positive effect on health. Emotion regulation which refers in this context to the ability to remain fundamentally optimistic in change, consists of expressing, influencing and changing one's own emotions. It is a skill that contributes significantly to change adaptability. This regulation can be described as trying to tune one's emotions positively even before a (negatively expected) event, choosing life situations in such a way that those which generate negative emotions from experience are avoided, consciously moving one's attention from the negative to the positive in difficult situations, re-framing the situation, i.e. seeing it in a different light, or even deliberately changing a feeling to the positive. In addition to Martin Seligman (2011) and Jon Kabat-Zin, who has done research primarily on meditation and mindfulness (Kabat-Zinn 2013), the seminal work of Barbara Fredrickson, especially the broaden-and-build theory (Fredrickson 2004), deserves special mention.

Positive emotions and emotion regulation are closely related to the concept of resilience. Resilience is a subject of study on its own and is a topic frequently covered in popular science. It is closely related to the other skills, positive emotion and emotion regulation.

Resilience goes back to the Latin re-silire = to jump back. In physics, it refers to material that returns to its original state after deformation. In psychology, it refers to the ability to fall back on positive resources in crises so that a higher level of resilience is built, and the person even develops further on a personal level. The most common definition of resilience outlines two aspects (Zautra et al. 2010): The capacity to recover quickly in or from a challenging situation and the ability to remain positive and healthy when facing situations of adversity.

Moreover, there are a variety of quite different descriptions of what resilience is. Resilience factors include, amongst others (Kumpfer 2002): Self-efficacy (the ability to live in a selfdetermined manner, to make plans and to implement them); Self-acceptance (the ability to accept oneself with one's strengths and weaknesses, to come to terms with one's history and to be able to affirm oneself fundamentally); Solution orientation (the ability to see problems as a challenge and to generate solutions); Optimism (the ability to maintain a positive outlook and to see the positive rather than the negative); Self-reflection (the ability to look at oneself, one's life and one's relationships from an excellent personal distance and to be able to make new decisions); Responsibility (the ability to take responsibility for oneself and others); Relationships (the ability to be able to enter into relationships, to be able to trust, to be socially active); Future (the ability to consciously shape the future and to want to do so).

According to the American Psychological Association (Palmiter 2012), there are 10 Ways to build resilience: Under the heading "build your connections", this includes prioritizing one-onone good, trusting, understanding and empathic relationships, as well as participation in a network of relationships in local and civil groups. "Foster wellness" includes activities to take care of one's body (food, sleep, exercise), mindfulness (yoga, spiritual life), and avoiding negative outlets such as drugs or alcohol. "Finding purpose" is achieved through concretely helping others, being proactive, setting and achieving goals, and seeing challenges as opportunities for personal growth. Finally, embracing healthy thoughts" means activities to direct one's thinking positively, to accept change, to keep hope and to learn from mistakes that have been made in the past. 
Behavioural adaptability: According to Pulakos et al. (2000), there are different dimensions of adaptive performance: Handling emergencies or crises; handling work stress; creative problem solving, dealing with uncertain and unpredictable work situations, learning work tasks; technologies and procedures, demonstrating interpersonal, cultural and physically oriented adaptability. Partly they could be part of comprehensive human-skill training, partly they can be accompanied by coaching and learned in a specific situation. For example, an adaptive crisis response model can help to reduce the complexity of a crisis, even if the crisis is identified early enough. (Ludescher 2013). As there are numerous ways to improve creative problem-solving skills, there is just one to mention, the CPS framework (Baumgartner 2021) that consists of the 7 steps: Clarify and identify the problem; Research the problem; Formulate creative challenges; Generate ideas; Combine and evaluate the ideas; Draw up an action plan; Do it.

The scientific literature distinguishes behavioural tendencies between reactive, tolerant and proactive behaviour. (Griffin, B., \& Hesketh, B. 2003). Proactive behaviour pays off for behavioural adaptability and can best be learned in everyday life by doing and feedback.

Then the coping styles problem-focused coping, emotion-focused coping and avoidance coping count towards behavioural adaptability. Robert Stensrud has presented a systematic approach on how stress coping skills can be learned in counselling. (Stensrud and Stensrud 1983).

Concerning the approach-avoidance motivation, there is also almost unmanageable literature, best summarized by Andrew Elliot (2008). In our context, the main point here is to learn to recognize the positive, motivating stimuli and let motivating triggers become bigger.

\section{How adults learn - a fundamental perspective}

Now that the three elements of change adaptability have been translated into practice-ready elements, the question is how they can be learned. To this end, it is first necessary to fundamentally reassure ourselves of how adults learn and how adults learn in a digital environment. Then - from practice - it is outlined how Resources for Change Adaptability in the remote environment can be developed and learned.

The main learning theories of adult learning can be found in andragogy, transformative learning, self-directed learning, project-based learning, and experiential learning.

Andragogy was made famous by Malcolm Knowles, who deliberately outlined adult learning in contrast to children learning. In particular, he emphasizes the importance of "why" or motivation in adult learning, building on prior knowledge, self-directed learning, and connecting the learner to his or her own reality (Knowles et al., 2012). Transformative learning goes back to Jack Mezirow and refers primarily to the fact that the learner reflects or even revises or at least changes his or her own experiences and views in the process of learning (Mezirow 2009). Self-directed learning has a long tradition and cannot be traced back to one author. Alan Tough, however, has developed it into a formal theory that places particular emphasis on the learner's own responsibility (Tough 1989). Finally, project-based learning is similar to experiential and action learning. It was advanced in particular by John Dewey (Alexander 1987).

The most comprehensive theory on adult learning can be found in Experiential Learning by David Kolb. Since the Experiential Learning approach encompasses many of the other approaches, we have chosen it as a reference. His original circle based on 4 dimensions (Concrete Experience; Reflective Observation; Abstract Conceptualization; Active Experimentation) has been extended over time and has been fundamentally enhanced in collaboration with or using concepts from many other renowned scientists such as William James, Kurt Lewin, Carl Robert, Carl Gustav Jung, John Dewey, Jean Piaget etc. (Kolb 2007). 
However, the aspects of learning types and the connections between learning and personality are out-of-scope for this paper. Therefore, we only consider the core of learning described in the above Learning Cycle or Learning Spiral.

Adult learning always starts with a concrete (new) experience. This has to be reflected and then abstracted. This abstract conceptualization then leads to acting, to active experimentation. This is how learning takes place (Kolb 2007). These four primary mechanisms of learning will now be explored in more depth. Experiencing requires full attention to the new learning experience. Therefore, "being present", which can be practised through mindfulness exercises, is essential here. Reflecting requires time. It is about seeing the present from a different perspective with empathy and calmness and then analyzing and reflecting on the information. Thinking requires the ability of abstraction to think through theoretical models and scenarios without immediately getting into action. Acting translates the first three steps into reality by setting goals and observing them in action.

Table 1: Kolb's Learning Phases, own demonstration

\begin{tabular}{|l|l|}
\hline Learning phase & Activity to enhance the capacity \\
\hline Experiencing & Being present \\
\hline Reflecting & Empathy; calmness; information analysis \\
\hline Thinking & Let go of emotions; theoretical model, and scenario building \\
\hline Acting & Goal setting, action initiating; Feedback receiving; performance monitoring \\
\hline
\end{tabular}

\section{How do adults learn remotely?}

Kolb's model is well suited to illustrate how adults learn in the best possible way. But now the question arises, whether Kolb's learning principles can be applied to remote learning and, if so, what the implications are. First, we need to define what we mean by "remote or distance learning". (Both expressions are used and applied similarly).

The topic "remote learning" has become virulent, not only with the pandemic. The first evidence of "distance learning" dates back to the 18th century (Holmberg 2008). In the 19th century, the system of Sir Isaac Pitman had become famous, who wrote something like "teaching letters" and got the students' answers for correction. (Tait 2003). In the following years, more and more universities offered so-called "correspondence courses". In the 20th century, distance learning received a substantial boost, first from radio and television and then from the spread of the Internet. Since the turn of the millennium, another massive change has occurred with the emergence of e-learning courses. In particular, the development of MOOCs (Massive Open Online Courses), which contain both traditional course material such as readings, recorded lessons, and assignments to be solved, but also offer interactive forums to allow an actual exchange between students and the students + faculty. The critical success factors regarding the remote learning environment consist of an appropriate course management system, an operational, technical infrastructure, user-friendly interface designs and interactive learning formats. Furthermore, from a facilitation perspective, critical success factors consist of clear learning objectives, high content quality, good learning strategies, high motivation through feedback and effective learning assessments (Cheawjindakarn et al., 2013). Some of the critical success factors are more technical (course management system, technical infrastructure, interface design), others more structural (interactivity; clear learning objectives; good learning strategies; learning assessments) or content-related (high content quality).

The practice has shown that all three elements are essential. For each type of distance/remote learning, the technical requirements for such training are given, i.e. a sound course management system, an operational, technical infrastructure and a good interface design. From experience, it can be said that a functioning internet connection with sufficient bandwidth and the appropriate communication system is the basis for functioning training. However, this aspect 
will not be discussed further since this is true for any remote/distance learning. The content aspect of high content quality also applies to any type of distant learning. Likewise, the structural elements of interactivity, clear learning objectives and learning assessments apply to all remote training.

So the question remains, how a good learning strategy can look like, which implements the crucial elements of Kolb's learning cycle.

In other words: How can the four steps of experimental learning (Experiencing/Thinking/ Reflecting/Acting) be structurally implemented in remote learning in a good learning strategy that allows strengthening cognitive, affective and behavioural adaptability?

\section{Conclusion}

In researching change adaptability, which is also especially required in times of a pandemic that brings a lot of change, we have examined the triad of cognitive, affective and behavioural adaptability, especially with the question of what these mean on a practical level. Then we selected a learning model, that of Experimental Learning, and outlined its basic implementation in the remote context. Now the phases of Experimental learning can be applied to the formulation of the three categories of change adaptability. Since remote learning requires a good learning strategy, we use the Experimental Learning strategy and apply it to the three cognitive, affective, and behavioural adaptability levels.

The Cognitive Resources can be divided into eleven different sub-themes. For the first three subtopics, situation awareness, cognitive flexibility, and focused attention, various experimental modalities are applied. The steps in adaptive orientation are similar. The first step of experimental learning is experiencing. Here, it is mainly about having a new experience that is perceived mindfully. Situation awareness is about becoming aware of the changing situation. Cognitive flexibility is about mindfully sensing the current state of flexibility, and focused attention is about mindfully perceiving all existing tasks. The second step, Reflecting, consists of an exercise in empathy. In situation awareness, one feels into the changing situation. In cognitive flexibility, one feels into increasing flexibility. In focused attention, one chooses a concrete task and empathically feels into it. In the third step, thinking can work with appropriate tools that allow one to approach a solution rationally. With situation awareness, a new model for a unique situation can be created. With cognitive flexibility, an exercise is carried out that promotes openness and creativity; with focused attention, a solution for the concrete problem is generated. The fourth step, acting, can be part of the remote training or done after the training. In situation awareness, clear goals are set for the change and work is done on implementation; in cognitive flexibility, openness and creativity are continued. Feedback on it is sought; in focused attention, work is done to implement the problem further.

The other sub-dimensions of adaptive orientation are similar so that they can be summarized here. In all areas, the first thing is to do a mindful exercise on the current status in Experiencing. This means to perceive how the respective attitude or skill is pronounced. In reflecting, again, an empathy exercise is done on the current status. In thinking, emotions are deliberately left out of the equation and solutions are soberly sought as to how the individual skill or attitude can be further developed and pronounced. Finally, acting is about setting clear goals, setting mechanisms in motion, how personal skill development can be observed and measured, and how feedback can be obtained.

The affective resources are very similar. It is about developing positive emotions and their recovery when they are weakened in a problematic situation. Resilience consists of these two movements but has other, different aspects. However, in all three Resilience movements, the first step, Experiencing, is again about mindful exercise about the skill or attitude in question. 
That is, it is about perceiving how much the skill is pronounced without getting into a judgment. In Reflecting, the empathy exercise is performed first. In thinking, it goes from emotion to reflection. For example, a model can be created of how certain positive emotions can be deepened. In acting, clear goals are then set, and consideration is given to how their achievement can be observed and measured.

The application of Experiential Learning concerning the 4 dimensions of behavioural resources is also very similar. The first step, Experiencing, is again about the mindful exercise of the respective skill. Reflecting is again an empathy exercise on information about the individual behaviour. In thinking, a model is created of how the desired behaviour can be strengthened and further developed, and in acting, the focus is on straightforward implementation.

Table 2: Kolb's Learning phases matched with Change Adaptability Elements

\begin{tabular}{|c|c|c|c|c|c|}
\hline $\begin{array}{l}\text { Cognitive } \\
\text { resources }\end{array}$ & $\begin{array}{l}\text { How it can be } \\
\text { supported/generated }\end{array}$ & Experiencing & Reflecting & Thinking & Acting \\
\hline $\begin{array}{l}\text { Situation } \\
\text { awareness }\end{array}$ & $\begin{array}{l}\text { raise awareness of the } \\
\text { need }\end{array}$ & $\begin{array}{l}\text { Mindful } \\
\text { exercise in a } \\
\text { changing } \\
\text { situation }\end{array}$ & $\begin{array}{l}\text { Empathy } \\
\text { exercise on a } \\
\text { changing } \\
\text { situation }\end{array}$ & $\begin{array}{l}\text { Exercise on } \\
\text { building a } \\
\text { new model }\end{array}$ & $\begin{array}{l}\text { Exercise on } \\
\text { executing the } \\
\text { new model }\end{array}$ \\
\hline $\begin{array}{l}\text { Mental } \\
\text { ability: } \\
\text { cognitive } \\
\text { flexibility }\end{array}$ & $\begin{array}{l}\text { think of new } \\
\text { solutions/models; } \\
\text { establish a mindset of } \\
\text { openness and creativity }\end{array}$ & $\begin{array}{l}\text { Mindful } \\
\text { exercise on the } \\
\text { current state of } \\
\text { flexibility }\end{array}$ & $\begin{array}{l}\text { Empathy } \\
\text { exercise on } \\
\text { increasing } \\
\text { flexibility }\end{array}$ & $\begin{array}{l}\text { Exercise on } \\
\text { how to } \\
\text { extend } \\
\text { openness and } \\
\text { creativity }\end{array}$ & $\begin{array}{l}\text { Exercise on } \\
\text { executing the } \\
\text { new model }\end{array}$ \\
\hline $\begin{array}{l}\text { Mental } \\
\text { ability: } \\
\text { focused } \\
\text { attention }\end{array}$ & $\begin{array}{l}\text { learning the Pomodoro } \\
\text { Technique }\end{array}$ & $\begin{array}{l}\text { Mindful } \\
\text { exercise on } \\
\text { current tasks }\end{array}$ & $\begin{array}{l}\text { Empathy } \\
\text { exercise on } \\
\text { current tasks }\end{array}$ & $\begin{array}{l}\text { think of how } \\
\text { to apply the } \\
\text { model }\end{array}$ & $\begin{array}{l}\text { Run the } \\
\text { Technique }\end{array}$ \\
\hline $\begin{array}{l}\text { Adaptive } \\
\text { orientation: } \\
\text { optimism }\end{array}$ & $\begin{array}{l}\text { Develop mechanisms } \\
\text { to enhance the } \\
\text { respective skill }\end{array}$ & $\begin{array}{l}\text { Mindful } \\
\text { exercise on the } \\
\text { current status }\end{array}$ & $\begin{array}{l}\text { Empathy } \\
\text { exercise on } \\
\text { information } \\
\text { about the } \\
\text { current status }\end{array}$ & $\begin{array}{l}\text { Build a } \\
\text { scenario of } \\
\text { how the } \\
\text { respective } \\
\text { skill can be } \\
\text { enhanced }\end{array}$ & $\begin{array}{l}\text { Set clear } \\
\text { goals, } \\
\text { including } \\
\text { monitoring } \\
\text { mechanisms }\end{array}$ \\
\hline $\begin{array}{l}\text { Adaptive } \\
\text { orientation: } \\
\text { hope }\end{array}$ & $\begin{array}{l}\text { Develop mechanisms } \\
\text { to enhance the } \\
\text { respective skill }\end{array}$ & $\begin{array}{l}\text { Mindful } \\
\text { exercise on the } \\
\text { current status }\end{array}$ & $\begin{array}{l}\text { Empathy } \\
\text { exercise on } \\
\text { information } \\
\text { about the } \\
\text { current status }\end{array}$ & $\begin{array}{l}\text { Build a } \\
\text { scenario of } \\
\text { how the } \\
\text { respective } \\
\text { skill can be } \\
\text { enhanced }\end{array}$ & $\begin{array}{l}\text { Set clear } \\
\text { goals, } \\
\text { including } \\
\text { monitoring } \\
\text { mechanisms }\end{array}$ \\
\hline $\begin{array}{l}\text { Adaptive } \\
\text { orientation: } \\
\text { self-efficacy }\end{array}$ & $\begin{array}{l}\text { Develop mechanisms } \\
\text { to enhance the } \\
\text { respective skill }\end{array}$ & $\begin{array}{l}\text { Mindful } \\
\text { exercise on the } \\
\text { current status }\end{array}$ & $\begin{array}{l}\text { Empathy } \\
\text { exercise on } \\
\text { information } \\
\text { about the } \\
\text { current status }\end{array}$ & $\begin{array}{l}\text { Build a } \\
\text { scenario of } \\
\text { how the } \\
\text { respective } \\
\text { skill can be } \\
\text { enhanced }\end{array}$ & $\begin{array}{l}\text { Set clear } \\
\text { goals, } \\
\text { including } \\
\text { monitoring } \\
\text { mechanisms }\end{array}$ \\
\hline $\begin{array}{l}\text { Adaptive } \\
\text { orientation: } \\
\text { control }\end{array}$ & $\begin{array}{l}\text { Develop mechanisms } \\
\text { to enhance the } \\
\text { respective skill }\end{array}$ & $\begin{array}{l}\text { Mindful } \\
\text { exercise on the } \\
\text { current status }\end{array}$ & $\begin{array}{l}\text { Empathy } \\
\text { exercise on } \\
\text { information } \\
\text { about the } \\
\text { current status }\end{array}$ & $\begin{array}{l}\text { Build a } \\
\text { scenario of } \\
\text { how the } \\
\text { respective } \\
\text { skill can be } \\
\text { enhanced }\end{array}$ & $\begin{array}{l}\text { Set clear } \\
\text { goals, } \\
\text { including } \\
\text { monitoring } \\
\text { mechanisms }\end{array}$ \\
\hline $\begin{array}{l}\text { Adaptive } \\
\text { orientation: } \\
\text { challenge }\end{array}$ & $\begin{array}{l}\text { Develop mechanisms } \\
\text { to enhance the } \\
\text { respective skill }\end{array}$ & $\begin{array}{l}\text { Mindful } \\
\text { exercise on the } \\
\text { current status }\end{array}$ & $\begin{array}{l}\text { Empathy } \\
\text { exercise on } \\
\text { information } \\
\text { about the } \\
\text { current status }\end{array}$ & $\begin{array}{l}\text { Build a } \\
\text { scenario of } \\
\text { how the } \\
\text { respective } \\
\text { skill can be } \\
\text { enhanced }\end{array}$ & $\begin{array}{l}\text { Set clear } \\
\text { goals, } \\
\text { including } \\
\text { monitoring } \\
\text { mechanisms }\end{array}$ \\
\hline
\end{tabular}




\begin{tabular}{|c|c|c|c|c|c|}
\hline $\begin{array}{l}\text { Adaptive } \\
\text { orientation: } \\
\text { open- } \\
\text { mindedness }\end{array}$ & $\begin{array}{l}\text { Develop mechanisms } \\
\text { to enhance the } \\
\text { respective skill }\end{array}$ & $\begin{array}{l}\text { Mindful } \\
\text { exercise on the } \\
\text { current status }\end{array}$ & $\begin{array}{l}\text { Empathy } \\
\text { exercise on } \\
\text { information } \\
\text { about the } \\
\text { current status }\end{array}$ & $\begin{array}{l}\text { Build a } \\
\text { scenario of } \\
\text { how the } \\
\text { respective } \\
\text { skill can be } \\
\text { enhanced }\end{array}$ & $\begin{array}{l}\text { Set clear } \\
\text { goals, } \\
\text { including } \\
\text { monitoring } \\
\text { mechanisms }\end{array}$ \\
\hline $\begin{array}{l}\text { Adaptive } \\
\text { orientation: } \\
\text { curiosity }\end{array}$ & $\begin{array}{l}\text { Develop mechanisms } \\
\text { to enhance the } \\
\text { respective skill }\end{array}$ & $\begin{array}{l}\text { Mindful } \\
\text { exercise on the } \\
\text { current status }\end{array}$ & $\begin{array}{l}\text { Empathy } \\
\text { exercise on } \\
\text { information } \\
\text { about the } \\
\text { current status }\end{array}$ & $\begin{array}{l}\text { Build a } \\
\text { scenario of } \\
\text { how the } \\
\text { respective } \\
\text { skill can be } \\
\text { enhanced }\end{array}$ & $\begin{array}{l}\text { Set clear } \\
\text { goals, } \\
\text { including } \\
\text { monitoring } \\
\text { mechanisms }\end{array}$ \\
\hline $\begin{array}{l}\text { Adaptive } \\
\text { orientation: } \\
\text { learning } \\
\text { orientation }\end{array}$ & $\begin{array}{l}\text { Develop mechanisms } \\
\text { to enhance the } \\
\text { respective skill }\end{array}$ & $\begin{array}{l}\text { Mindful } \\
\text { exercise on the } \\
\text { current status }\end{array}$ & $\begin{array}{l}\text { Empathy } \\
\text { exercise on } \\
\text { information } \\
\text { about the } \\
\text { current status }\end{array}$ & $\begin{array}{l}\text { Build a } \\
\text { scenario of } \\
\text { how the } \\
\text { respective } \\
\text { skill can be } \\
\text { enhanced }\end{array}$ & $\begin{array}{l}\text { Set clear } \\
\text { goals, } \\
\text { including } \\
\text { monitoring } \\
\text { mechanisms }\end{array}$ \\
\hline \multicolumn{6}{|c|}{ Affective resources } \\
\hline $\begin{array}{l}\text { Positive } \\
\text { emotions }\end{array}$ & Staying positive & $\begin{array}{l}\text { Mindful } \\
\text { exercise on } \\
\text { positivity }\end{array}$ & $\begin{array}{l}\text { Empathy } \\
\text { exercise on } \\
\text { information } \\
\text { about staying } \\
\text { positive }\end{array}$ & $\begin{array}{l}\text { Build a } \\
\text { model how to } \\
\text { establish a } \\
\text { positive state } \\
\text { of mind }\end{array}$ & $\begin{array}{l}\text { Set clear } \\
\text { goals, } \\
\text { including } \\
\text { monitoring } \\
\text { mechanisms }\end{array}$ \\
\hline $\begin{array}{l}\text { Emotion } \\
\text { regulation }\end{array}$ & Recover quickly & $\begin{array}{l}\text { Mindful } \\
\text { exercise on } \\
\text { recovering } \\
\text { experiences }\end{array}$ & $\begin{array}{l}\text { Empathy } \\
\text { exercise on } \\
\text { information } \\
\text { about } \\
\text { recovering } \\
\text { experiences }\end{array}$ & $\begin{array}{l}\text { Build a } \\
\text { model on } \\
\text { how to } \\
\text { recover } \\
\text { quickly when } \\
\text { having lost } \\
\text { positivity }\end{array}$ & $\begin{array}{l}\text { Set clear } \\
\text { goals, } \\
\text { including } \\
\text { monitoring } \\
\text { mechanisms }\end{array}$ \\
\hline
\end{tabular}

\section{Conclusion}

This study bridges the gap between change adaptability as a theoretical concept, its practical implications, its connection to a learning theory concept, and its implementation in the remote environment. However, due to the study setup, there are some limitations. First, there is the limitation to the respective main concepts of change adaptability and adult learning. Then, some elements of remote learning had to be disregarded, and it could not be fundamentally distinguished whether the subjects of the learning were from companies, universities or other institutions.

Change adaptability is in itself a topic that has only begun to be studied. There is a need for many more studies that (1) further explore the concept of change adaptability, (2) examine its application to different professions, and (3) examine its application to different cultures. There is also a need for more studies that fundamentally examine the effectiveness of remote learning and remote training. Furthermore, there are no standardized measurement scales that can be applied to the individual dimensions of Change Adaptability.

One thing is sure: In a world that is changing ever faster, people's ability to adapt to change and deal with it positively, using remote learning opportunities, is becoming increasingly important.

\section{References}

Alexander, T. M. (1987). John Dewey's theory of art, experience, and nature. The horizons of feeling. Albany, NY: State Univ. of New York Press (SUNY series in philosophy).

Araya, D. (2020). What the future of learning looks like in a digital economy. Available online at https://www.futurithmic.com/2020/08/07/what-future-learning-looks-like-digital-economy/. 
Baumgartner, J. (2021). The Basics of Creative Problem Solving - CPS. Available online at https://innovationmanagement.se/2010/06/02/the-basics-of-creative-problem-solving-cps/, updated on 2/11/2021.

Beck, Aaron T. (2019). A 60-Year Evolution of Cognitive Theory and Therapy. In Perspectives on psychological science: a journal of the Association for Psychological Science 14 (1), pp. 16-20. DOI: $10.1177 / 1745691618804187$.

Besser, A., Flett, G. L., \& Zeigler-Hill, V. (2020). Adaptability to a sudden transition to online learning during the COVID-19 pandemic: Understanding the challenges for students. In Scholarship of Teaching and Learning in Psychology.

Cheawjindakarn, B., Suwannatthachote, P., \& Theeraroungchaisri, A. (2013). Critical success factors for online distance learning in higher education: A review of the literature. In Creative Education, 3(08), 61.

Cirillo, Francesco (2006). The pomodoro technique. The acclaimed time-management system that has transformed how we work. 2018 Currency edition. New York: Currency, an imprint of Crown Publishing Group, a division of Penguin Random House LLC.

Elliot, Andrew J. (2008). Handbook of approach and avoidance motivation. New York NY, Hove: Psychology Press Taylor \& Francis Group.

Ellis, Albert; MacLaren, Catharine (2001). Rational emotive behavior therapy. A therapist's guide. Atascadero, Calif.: Impact Publishers (The practical therapist series).

Endsley, M. R. (1995). “Towards a theory of situation awareness in dynamic environments,”. In Human Factors, 37, 32-64.

Fredrickson, Barbara L. (2004). The broaden-and-build theory of positive emotions. In Philosophical transactions of the Royal Society of London. Series B, Biological Sciences 359 (1449), pp. 1367-1378. DOI: 10.1098/rstb.2004.1512.

Green, Crystal; Mynhier, Laurelyn; Banfill, Jonathan; Edwards, Phillip; Kim, Jungwon; Desjardins, Richard (2021). Preparing education for the crises of tomorrow: A framework for adaptability. In International review of education. Internationale Zeitschrift fur Erziehungswissenschaft. Revue internationale de pedagogie, pp. 1-23. DOI: 10.1007/s11159-020-09878-3.

Griffin, B., \& Hesketh, B. (2003). Adaptable behaviours for successful work and career adjustment. In Australian Journal of Psychology, 55(2), 65-73.

Hagemann, Michael (2020). Three key success factors for transforming your business. Mindset, infrastructure, capability. First edition. New York, New York (222 East 46th Street, New York, NY 10017): Business Expert Press (Human resource management and organizational behavior collection).

Harvard Health Publishing (2017). Foods linked to better brainpower. Available online at https://www.health.harvard.edu/mind-and-mood/foods-linked-to-better-brainpower, checked on $2 / 11 / 2021$.

Holmberg, Börje (2008). The evolution, principles and practices of distance education. Oldenburg: Bibliotheksund Informationssystem der Univ (Studien und Berichte der Arbeitsstelle Fernstudienforschung der Carlvon-Ossietzky-Universität Oldenburg, 11). Available online at http://www.unioldenburg.de/fileadmin/user_upload/c31/master/mde/download/asfvolume11_eBook.pdf.

Judge, T. A., Thoresen, C. J., Pucik, V., \& Welbourne, T. M. (1999). Managerial coping with organizational change: A dispositional perspective. In Journal of applied psychology, 84(1), 107.

Kabat-Zinn, Jon (2013). Gesund durch Meditation. Das vollständige Grundlagenwerk zu MBSR. Vollständig überarbeitete Neuausgabe. München: O.W. Barth.

Knowles, Malcolm Shepherd; Holton, Elwood F.; Swanson, Richard A. (2012). The adult learner. The definitive classic in adult education and human resource development. Seventh edition. London, New York: Routledge.

Kolb, D. A. (2007). The Kolb learning style inventory. Boston, MA: Hay Resources Direct.

Kumpfer, K. L. (2002). Factors and processes contributing to resilience. In resilience and development (pp. 179224). Springer, Boston, MA.

Ludescher, Aldric F. (2013). Coping with Crisis and Complexity. A complexity science-informed approach to crisis management. Master Thesis. FH Campus Wien, Wien. Risk Management. Available online at https://www.researchgate.net/publication/259885706_Coping_with_Crisis_and_Complexity_-

A_complexity_science-informed_approach_to_crisis_management, checked on 2/11/2021.

Mezirow, Jack (2009). Transformative learning in practice. Insights from community, workplace, and higher education. San Francisco, CA: Jossey-Bass.

Nehlig, Astrid (2010). Is caffeine a cognitive enhancer? In Journal of Alzheimer's disease: JAD 20 Suppl 1, 8594. DOI: 10.3233/jad-2010-091315.

Palmiter, D. et al. (2012). Building your resilience. Available online at https://www.apa.org/topics/resilience, checked on $2 / 11 / 2021$. 
Ployhart, R.; Bliese, P. (2006). Individual Adaptability (I-ADAPT) Theory: Conceptualizing the Antecedents, Consequences, and Measurement of Individual Differences in Adaptability. In C. Shawn Burke (Ed.): Understanding adaptability. A prerequisite for effective performance within complex environments, vol. 6. 1. ed. Amsterdam: Elsevier JAI (Advances in human performance and cognitive engineering research, 6), pp. 3-39.

Pulakos, E. D., Arad, S., Donovan, M. A., \& Plamondon, K. E. (2000). Adaptability in the workplace: Development of a taxonomy of adaptive performance. In Journal of applied psychology, 85(4), 612.

Rasch, Björn; Born, Jan (2013). About sleep's role in memory. In Physiological reviews 93 (2), pp. 681-766. DOI: 10.1152/physrev.00032.2012.

Seligman, Martin E. P. (2011). Learned optimism. How to change your mind and your life. New York: Simon \& Schuster Audio.

Stensrud, Robert; Stensrud, Kay (1983). Coping Skills Training: A Systematic Approach to Stress Management Counseling. In Personnel \& Guidance Journal 62, pp. 214-218. DOI: 10.1111/j.2164-4918.1983.tb00189.x.

Tait, A. (2003). Reflections on Student Support in open and distance learning. Available online at http://www.irrodl.org/index.php/irrodl/article/view/134/214, checked on 1/30/2021.

Tough, A. M. (1989). Self-directed Learning: Concepts and Practice. In Colin J. Titimus (Ed.): Lifelong Education for Adults: Advances in Education. Amsterdam: Pergamon, pp. 256-260. Available online at https://www.sciencedirect.com/science/article/pii/B9780080308517500825.

van Dam, K. (2011). "Cognitive resources of individual adaptability,". Paper for the 15th European Congress of Work and Organizational Psychology, Maastricht, Netherlands.

van Dam, K. (2013a). Employee adaptability to change at work: A multidimensional, resource-based framework. In The psychology of change: Viewing change from the employee's perspective, 123-142.

van Dam, Karen (2009). Employee adaptability to change at work: a multidimensional, resource-based framework, pp. 123-142. DOI: 10.1017/CBO9781139096690.009.

van Dam, Karen (2013b). Employee adaptability to change at work: A multidimensional, resource-based framework. In The psychology of change: Viewing change from the employee's perspective, 123-142.

Wanberg, C. R., \& Banas, J. T. (2000). Predictors and outcomes of openness to changes in a reorganizing workplace. In Journal of applied psychology, 85(1), 132.

Xu, S., Jiang, X., \& Walsh, I. J. (2018). The influence of openness to experience on perceived employee creativity: The moderating roles of individual trust. In The Journal of Creative Behavior, 52(2), 142-155.

Zautra, A. J., Hall, J. S., \& Murray, K. E. (2010). Resilience: a new definition of health for people and communities. Handbook of Adult Resilience. 